\title{
A Simple Public Debt Dynamic Model for Assessing Fiscal Vulnerability: Empirical Evidence for EU Countries
}

\author{
Andreea Stoian \\ Dept. of Finance, Bucharest Academy of Economic Studies \\ Piata Roman, no.6, District 1, Room 1104, Zip Code 010374, Bucharest, Romania \\ Tel: 40-21-319-1901Ｅ-mail: andreea.stoian@fin.ase.ro
}

Received: September 2, 2011 Accepted: November 10, 2011 Published: December 28, 2011

doi:10.5296/rae.v3i2.1137ＵRL: http://dx.doi.org/10.5296/rae.v3i2.1137

\begin{abstract}
There is a large body of research showing that fiscal policy confronted growing challenges over the last decades. The increasing public debt along with population ageing made fiscal policy more vulnerable, in the sense of having some exposure to liquidity and/or solvency risks. In this context, the question arises on how to assess fiscal vulnerability as to signal government to adjust the policy and to restore it to the 'good' path. The aim of this paper is to introduce a new methodology of assessing fiscal vulnerability based on a simple dynamic model of public debt. Using annual data ranged on 1970-2012 for all European Union countries, the results show the moments when fiscal policy was vulnerable.
\end{abstract}

Keywords: Fiscal policy, Primary balance, Public debt, Fiscal sustainability 


\section{Introduction}

Numerous recent studies have brought into attention the issue of substantial increasing of public debt. For instance, Ghosh, Kim, Mendoza, Ostry and Qureshi (2011) considered that stimulus spending and lower revenues in the Great Recession contributed to some of the highest ratios to GDP of public debt and primary deficits in advanced economies seen in the past forty years and many of these countries are expected to continue facing large financing needs over the coming years. Reinhart and Rogoff (2011) also pointed out that public debt have surged in recent years to levels not recorded since the end of World War II. Scott (2010) addressed the problem of the current financial crisis, considering that government debt in a number of countries is expected to show substantial increases, and this will generate concerns that government debt will reach unsustainable levels.

Increasing public debt may lead to non-sustainable fiscal policy in the long run. Ciarlone and Trebeschi (2006) pointed out that issuing more debt to finance fiscal deficit (including interest payments) and/or principal arrears from previous years can endanger government's liquidity and solvency. Moreover, increasing public debt can affect national income allocation among consumers and stabilization function of government. A misuse of government borrowings may have a negative impact on consumers' decisions and their expectations. The conventional view highlights the long term effects of public debt. In the short term, budgetary deficit increases consumption. If the workforce is totally employed, increasing consumption lowers savings in the long run. Financing deficits by government borrowings increases interest rates and capital accumulation rate may decrease in the long run.

It is quite clear that fiscal policy worldwide confronts with growing challenges that make it vulnerable, in the sense of exposing it to liquidity and/or solvency risks. In this context, the question on how to assess the fiscal vulnerability arises. This research is important considering that a vulnerable fiscal policy can be a cause of currency or debt crisis, can expose economy to various risks and can endanger sustainability in the long run. The recent financial turmoil showed to some extent that fiscal policy was not able to absorb this shock and consistent severe fiscal adjustments were strongly needed. The aim of this paper is to introduce a new model for assessing fiscal vulnerability. In accordance with this purpose, the study starts with shedding some light on the concept of fiscal vulnerability in Section 2. In Section 3, it is presented the model for assessing fiscal vulnerability that grounds on the dynamic equation of public debt. Section 4 consists in the database and empirical evidence for the case of European Union countries. The last section gives the concluding remarks of this study.

\section{Defining fiscal vulnerability}

David Friedman (American economist) stated at one of his well known lectures that even if peoples generally know that 'market failure' means that 'market fails' or 'theory of relativity' implies that 'everything is relative', there are only few that can understand correctly the exact content of this concepts. The situation is also similar in the case of 'fiscal vulnerability'. There are many authors who dealt with fiscal vulnerability issues, but there are only few that provided some comprehensive definitions of it. 
Generally speaking, Furman and Stiglitz (1999) defined a vulnerable economy considering the increased probability that the economic system cannot absorb all the shocks (speculative attacks on national currency) and, therefore, it transforms them into systemic risk(Note 1). Allen et al (2002) and Rial and Vicente (2004) pointed out that the economy is vulnerable when there is a liquidity or solvency risk(Note 2). Frankel and Saravelos (2010) stated that a country is more vulnerable if it experienced larger output drops, bugger stock market falls, greater currency weakness, larger loss in reserves, or the need for access to International Monetary Fund financial assistance(Note 3).

Related strictly to the concept of 'fiscal vulnerability', Brixi, Shatalov and Zlaoui (2000) defined fiscal risk as government's ability to meet all its future payments. Any change that goes to an increase of government's payment obligations induces a certain risk and can generate excessive fiscal deficits and public debt stocks in the long run. In that sense, Detragiache and Spilimbergo (2001) found that less liquid countries are more likely to default on their external debt, and the probability of a crisis increases with the proportion of short term debt and debt service. Also, Hayes (2011) referred to large government deficit and high reliance on external debt as sources of vulnerability(Note 4) Recently, Aizenman and Pasricha (2010) and Baldacci, McHugh and Petrova (2011) focused on fiscal fragility, or fiscal vulnerability and fiscal stress but they gave no definition. They related these concepts, somehow counterintuitive, with the liquidity and solvency constraints. Later on, Baldacci et al (2011) have defined the fiscal crisis periods as episodes of public debt default or restructuring, need to access large-scale official or IMF support, hyperinflation, that endanger fiscal solvency.

Hemming and Petrie (2000), and Hemming, Kell and Schimmelpfennig (2003) are the only that formulated a comprehensive definition of fiscal vulnerability considering the macroeconomic objectives aimed by the government(Note 5): to avoid excessive fiscal deficits and public debt stocks that can threaten macroeconomic stability in the short run and fiscal sustainability in the long run; to design a flexible fiscal policy that assures the immediate reaction to domestic and external disequilibrium, and/or to assure a stable and a proper taxation rate that allows for collecting sufficient fiscal revenues for the public budget.

Considering all the previous statements, fiscal policy is said to be vulnerable whenever government fails in assuring adequate financial resources (trough taxation or borrowing) to meet all its payment obligations. But how can government recognize when fiscal policy enters into a vulnerable fiscal condition? Large fiscal deficit and/or public debt stock may represent leading indicators that signal when fiscal policy turns out to be vulnerable to some degree. But sometimes, large fiscal deficits can be occasionally and not necessarily imply a liquidity and/and or solvency risk. Chuhan (2005), for instance, argued that public debt can give useful information about government's ability to pay, but cannot provide details on all the dimensions of the payment problem. In this context, it is important to find a relevant tool to assess fiscal vulnerability.

\section{Public debt dynamic model}

There are many studies focusing on how to predict financial crisis (currency and/or debt crisis) 
that ground on the assumption that a vulnerable fiscal policy may be a cause of such distress situations (e.g., Ciarlone and Trebeschi, 2006; Tanner and Samake, 2006; York and Zhan, 2009). They developed models of early warning signal that incorporate fiscal indicators. There are only few relevant studies that gave attention to fiscal vulnerability itself and to assessment methods. For instance, Hemming and Petrie (2000) presented various indicators (i.e. fiscal position indicators, short-term fiscal risk indicators, longer-term sustainability indicators, expenditures and revenue indicators, fiscal management indicators and government effectiveness indicators) that may be used to measure fiscal vulnerability, but gave no methodology in that sense. Later on, Hemming, Kell and Schimmelpfennig (2003) shortly brought into attention three different methods of assessing fiscal vulnerability that uses financial market indicators, Value-at-Risk method, and sources of fiscal vulnerability. But their research also focused on early warning signal debt crisis model that incorporates fiscal policy. Rial and Vicente (2004) proposed a set of vulnerability indicators that quantify and evaluate risk related to the volatility of debt determinants, asserting that debt-to-GDP ratio is sensitive to changes in relative prices, GDP growth rate and reference interest rate. York and Zahn (2009) evaluated fiscal vulnerability for eight world's oil producing countries using primary balance and fiscal revenues as relevant indicators. The analysis is purely statistical based on historical data. Baldacci and McHugh (2011) and Baldacci et al (2011) proposed a fiscal vulnerability index that measures the degree of fiscal vulnerability on a continuous basis as departure of key fiscal variables from their historical "norms", defined as 10 -year cross-country averages.

Therefore, considering the previous literature on that topic, one can notice that there is still room for improvement. This study aims to present a new methodology for assessing fiscal vulnerability that uses the event studies approach for the capital markets, firstly introduce by Fama, Fisher, Jensen and Roll (1969). The suggested methodology is based on the generally accepted definition of fiscal vulnerability, which states that fiscal policy is vulnerable when it is exposed to some liquidity/solvency risks. Thus, one can assess fiscal vulnerability using a simple model of public debt dynamic that allows for the estimation of a required primary balance, knowing the rate of growth of public debt. This can work as a fiscal rule. One can argue that whenever government is not able to meet the required primary balance this may imply postponed higher taxes or less government spending or increasing future public debt. Thus, governments should meet the level of the required primary balance. The generally accepted view is that the current primary balance to be larger than the required one. This implies that government is able to generate primary surplus to meet its payment obligations, or at least to reduce deficits. Consequently, public debt can decrease. In this context, running primary surplus larger than the required one for consecutive years may be an effect of higher taxation and/or lower spending than it is necessary for that moment or than automatic stabilizers imply. In the long run, such a restrictive fiscal policy may negatively affect economic growth and large fiscal imbalances may occur. Therefore, the over-achievement of the fiscal rule may represent postponed fiscal deficits. Thus, for the model we assume a very restrictive hypothesis that a good fiscal policy is one that meets strictly the required primary balance. Second, the errors between the required primary balance and the current primary balance are calculated and represent the excess primary balance (EPB). Third, using the event 
studies technique for the capital markets, the errors are summed up for the calculation of the cumulative excess primary balance (CEPB). Then, CEPB is squared for the purpose of treating likewise the negative and the positive errors, considering the above argue. The squared cumulative excess primary balance (SQEPB) is computed. The extended methodology is presented below.

\subsection{The required primary balance}

One can assess the required primary balance $\left(p^{*}\right)$ using the dynamic equation of public debt and assuming that debt is issued for one period. At time $t$, government has to borrow money $\left(B_{t}\right)$ to finance the primary deficit (the difference between primary expenditures, $G_{t}$, and government revenues, $\left.V_{t}\right)$, interest payment related to previous year $\left(i \cdot B_{t-1}\right)$, and public debt from previous year $\left(B_{t-1}\right)$ :

$$
B_{t}=G_{t}-R_{t}+B_{t-1}+i \cdot B_{t-1}
$$

where:

$i$ : nominal interest rate.

Rearranging equation (1), a different form is obtained:

$$
B_{t}-B_{t-1}=G_{t}-R_{t}+i \cdot B_{t-1}
$$

Considering the variables as ratios to GDP (small caps denote that), equation 1 becomes:

$$
\begin{aligned}
& \frac{B_{t}-B_{t-1}}{B_{t-1}} \cdot \frac{B_{t-1}}{Y_{t-1}}=\left(\frac{G_{t}}{Y_{t}}-\frac{R_{t}}{Y_{t}}\right) \cdot \frac{Y_{t}}{Y_{t-1}}+i \cdot \frac{B_{t-1}}{Y_{t-1}} \Leftrightarrow \\
& \theta \cdot b_{t-1}=p_{t} \cdot(1+g)+i \cdot b_{t-1}
\end{aligned}
$$

where:

$\theta=$ relative dynamic of public debt stock;

$p_{t}=$ primary deficit GDP-ratio, at time $t$;

$b_{t-1}=$ public debt GDP-ratio at time $t-1$;

$g=$ nominal growth rate;

$i=$ nominal interest rate on public debt.

Consequently, the required primary surplus at time $t\left(p_{t}^{*}\right)$ is given by:

$$
p^{*}{ }_{t}=-\frac{\theta-i}{1+g} \cdot b_{t-1}
$$

Equation (4) gives the required primary balance considering the dynamic of public debt. This may work as a fiscal rule that should be met exactly by governments. Comparing the required primary balance $\left(p_{t}^{*}\right)$ with the current one $\left(p_{t}\right)$, one can state that fiscal may be 'good', at least, whenever $p_{t}{ }^{*}=p_{t .}$. The generally accepted idea is that fiscal policy is 'good' and sustainable in the long run if $p_{t}{ }^{*}<p_{t}$. (see for instance, Pasinetti, 1998). For the purpose of this study, we assume a much restrictive hypothesis that fiscal policy is ' $g o o d$ ' whenever $p_{t}{ }^{*}=$ $p_{t .}$. The case when $p_{t}{ }^{*}>p_{t}$ is obviously the case of a 'bad' fiscal policy. If government achieves 
lower/higher primary surplus/deficit than the required one for many consecutive years, this will lead to increasing borrowing for the financing purposes, but it may expose economy to liquidity and/or solvency risks. Also, the opposite situation, when $p_{t}^{*}<p_{t}$ may be tricky and fool the government! Generating primary surpluses or running primary deficits more/less than the required one for many consecutive years may be a result of a much restrictive fiscal policy than the automatic stabilizers imply, and, consequently economic growth may be endangered in the long run. Or, higher surpluses/lower deficits may stimulate government to increase expenditures and these can turn into large deficits in the medium term. In more general opinion, this achievement would be good, and having more revenues to finance government expenditures will reduce government borrowings.

\subsection{Excess Primary Balance (EPB)}

The errors between the required primary balance $\left(p_{t}^{*}\right)$ and the current primary balance $\left(p_{t}\right)$ are calculated. These represent the excess primary balance (EPB) and give the deviations of the current fiscal policy from the fiscal rule:

$$
E P B-p_{t}^{s}-p_{t}
$$

It can be argued that each time fiscal policy fails in achieving the fiscal rule the errors represent deviations from a 'good' policy. In the medium and long run, these deviations may cause larger budgetary deficits and public debt stocks. Thus, we choose to treat the positive and the negative errors likewise.

\subsection{Squared Cumulative Excess Primary Balance (SQCEPB)}

Following the event study technique for the capital markets (Fama, Fisher, Jensen and Roll, 1969), the errors are summed up to capture the accumulated effect of the deviations from the fiscal rule in the long run. Considering that all the deviations (positive or negative) are treated likewise, the sum of the cumulative errors is squared, representing the squared cumulative excess primary balance:

$$
S Q C E P B=\left(\sum_{i=1}^{N}\left(p_{t}^{*}-p_{t}\right)_{i}\right)^{2}
$$

\section{$N$ : observations.}

The expected result is that an increasing SQCEPB shows that fiscal policy entered into a vulnerable condition. A decreasing SQCEPB reveals that governments adjusted fiscal policy to restore the primary balance more closely to the fiscal rule. The empirical evidence is presented below.

\section{Assessing fiscal vulnerability for European Union countries (EU-27)}

There is a large body of research showing that in the last 30 years, fiscal position has not significantly changed for most of the European countries and that fiscal policy in the euro area has been mildly pro-cyclical (i.e. Fatas and Mihov, 2009; Afonso, Agnello, Furceri and Sousa, 2009). Many other studies brought into attention that fiscal policy in European Union 
(EU) is unsustainable in the long run (i.e. Afonso, 2000; Afonso and Rault, 2008). In addition, Corsetti and Roubini (1996), Alesina (2000), and Kotlikoff and Hagist (2005) predicted that current fiscal policies of most EU countries based on growing social spending will become unsustainable in the future and the governments will have to adjust their fiscal policies sooner or later (Balassone et al, 2009). Drawing the conclusions from previous literature, it is quite clear that the fiscal policy in EU is confronted with various difficulties and we may assume that fiscal policy is vulnerable and may have an exposure to liquidity and/or solvency risk.

In addition, empirical evidence shows that public debt-to-GDP ratio varies across EU-27 with different standard deviation (see Figure 1):

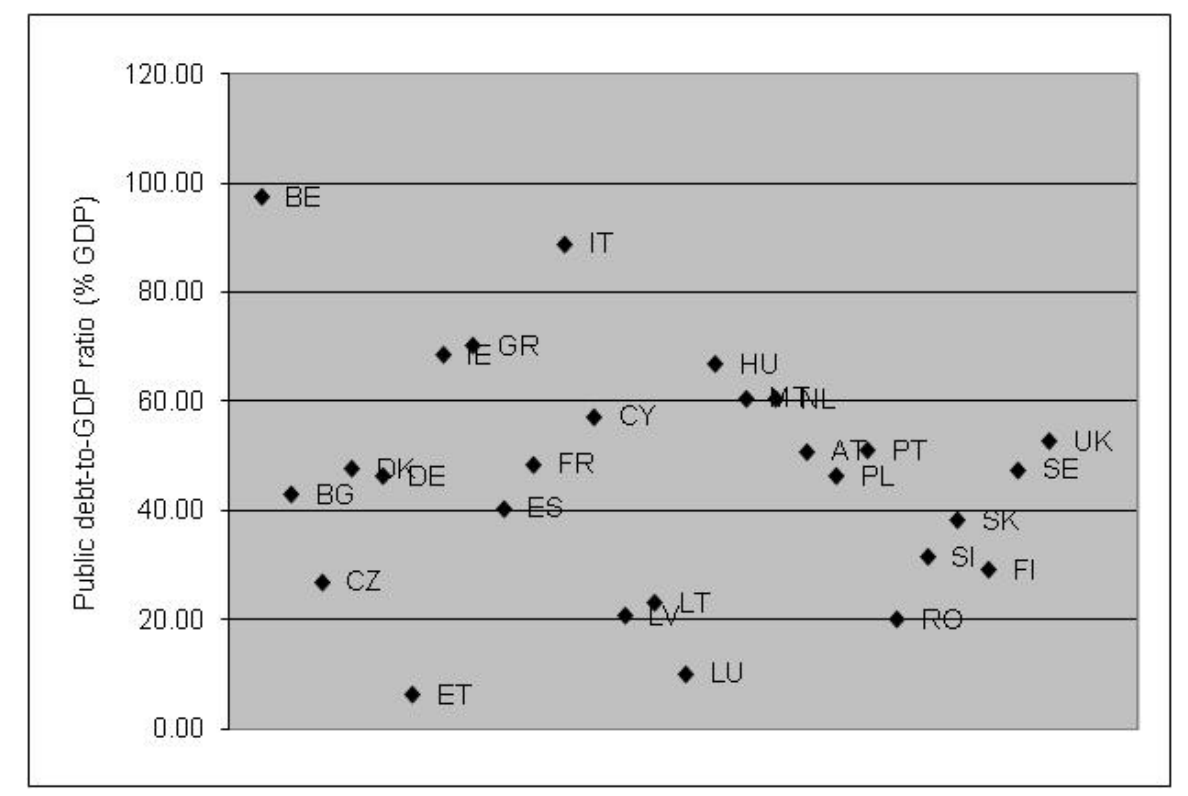

Figure 1. Public debt-to-GDP ratio in EU countries

Public debt-to-GDP ratio annual average based on data available from Eurostat extracted from 1970-2012

There are cases with very low public debt-to-GDP ratios (e.g. Estonia and Luxembourg) and countries with ratios that exceed $60 \%$ of GDP (e.g. Ireland, Greece, Hungary, Italy, and Belgium). For the rest of the countries, public debt-to-GDP ratio is between $20 \%$ and $40 \%$ of GDP (see also Table 1).

Table 1. Standard deviation for public debt-to-GDP ratio

\begin{tabular}{|c|c|c|c|c|c|c|c|c|c|c|}
\hline BE & BG & CZ & DK & DE & ET & IE & GR & ES & FR & IT \\
\hline 25.7 & 28.9 & 10.2 & 21.9 & 18.2 & 2.1 & 27.8 & 41.4 & 19.4 & 20.4 & 27.0 \\
\hline CY & LV & LT & LU & HU & MT & NL & AT & PL & PT & RO \\
\hline 9.7 & 15.4 & 10.1 & 4.7 & 10.4 & 10.8 & 12.9 & 18.2 & 6.5 & 17.8 & 7.8 \\
\hline SI & SK & FI & SE & UK & & & & & & \\
\hline 8.5 & 8.3 & 18.2 & 15.0 & 13.5 & & & & & & \\
\hline
\end{tabular}

Standard deviation is calculated based on annual data for public debt-to-GDP ratio available from Eurostat

Standard deviation for public debt-to-GDP ratio shows large variance for some countries of 


\section{Mll Macrothink}

Research in Applied Economics

ISSN 1948-5433

2011, Vol. 3, No. 2: E3

those whose public debt-to-GDP ratios exceeded $60 \%$ of GDP for many consecutive years (e.g. Belgium, Ireland, Greece, and Italy). For other cases, the ratio was below $100 \%$ of GDP, but above 60\% (e.g. Denmark, Germany, Spain, France, Cyprus, Hungary, Malta, the Netherlands, Austria, Portugal, Sweden and United Kingdom). One can observe that most of the advanced European Union economies had large public debt. The new comers in EU, mostly Central and East European countries, recorded lower indebtedness rate. But one can argue whether public debt-to-GDP ratio may be considered a relevant indicator of assessing if government fiscal policy is 'good' or 'bad'. For instance, government may run large public debt-to-GDP ratio, but if it manages to borrow 'cheap' money at a cost lower than the economic growth, the exposure to liquidity and/or solvency risk may be reduced than in the case of a country with lower ratio of public debt that is financed through expensive. Thus, analyzing only the public debt-to-GDP ratio can be misleading. Adding some information about the cost and the rate of growth of public debt and about the GDP growth rate can give extra details about the soundness of fiscal policy (see Table 2):

Table 2. Average implicit interest rate on public debt, public debt growth, GDP growth rate

\begin{tabular}{|l|c|c|c|c|c|}
\hline & $\begin{array}{c}\text { Implicit interest } \\
\text { rate }(i, \%)\end{array}$ & $\begin{array}{c}\text { Public debt } \\
\text { growth }(\theta, \%)\end{array}$ & $\begin{array}{c}\text { GDP growth } \\
(g, \%)\end{array}$ & $\theta>g$ & $i>g$ \\
\hline Belgium & 7.4 & 8.1 & 6.7 & Yes & Yes \\
\hline Bulgaria & 5.2 & 0.0 & 10.0 & No & No \\
\hline Czech Republic & 5.6 & 17.5 & 8.5 & Yes & No \\
\hline Denmark & 10.1 & 12.5 & 6.6 & Yes & Yes \\
\hline Germany & 6.3 & 10.5 & 6.6 & Yes & No \\
\hline Estonia & 5.2 & 13.1 & 11.0 & Yes & No \\
\hline Ireland & 6.1 & 8.4 & 7.1 & Yes & No \\
\hline Greece & 8.9 & 10.8 & 6.0 & Yes & Yes \\
\hline Spain & 5.4 & 6.9 & 5.5 & Yes & No \\
\hline France & 6.5 & 10.1 & 5.2 & Yes & Yes \\
\hline Italy & 8.5 & 8.1 & 5.7 & Yes & Yes \\
\hline Cyprus & 5.6 & 9.8 & 9.0 & No & No \\
\hline Latvia & 6.4 & 22.4 & 10.8 & Yes & No \\
\hline Lithuania & 6.5 & 22.1 & 11.5 & Yes & No \\
\hline Luxembourg & 5.5 & 10.0 & 8.8 & Yes & No \\
\hline Hungary & 8.5 & 7.9 & 7.2 & Yes & Yes \\
\hline Malta & 5.9 & 10.1 & 5.4 & Yes & Yes \\
\hline Netherlands & 7.3 & 7.7 & 6.0 & Yes & Yes \\
\hline Austria & 6.3 & 9.9 & 6.3 & Yes & No \\
\hline Poland & 7.5 & 11.0 & 8.2 & Yes & No \\
\hline Portugal & 9.5 & 10.9 & 6.6 & Yes & Yes \\
\hline Romania & 17.5 & 24.7 & 10.8 & Yes & Yes \\
\hline Slovenia & 5.8 & 11.3 & 5.0 & Yes & Yes \\
\hline Slovakia & 6.9 & 15.9 & 10.1 & Yes & No \\
\hline Finland & 8.1 & 13.0 & 6.5 & Yes & Yes \\
\hline Sweden & 5.1 & 7.8 & 3.5 & No & Yes \\
\hline UK & 7.7 & 7.0 & Yes & Yes \\
\hline
\end{tabular}

Author's estimation based on annual data available from Eurostat

Implicit interest rate is derived as nominal interest expenditure divided by previous period debt stock; $\theta$ - annual relative dynamic of public debt stock; $g$ - annual relative GDP growth rate 


\section{Macrothink}

We may observe that there are only few countries (Bulgaria, Cyprus, and Sweden) that had a relative dynamic of public debt lower than the GDP growth rate. In rest of the cases public debt accumulated more rapidly than the economy rose. Concerning the differential between the implicit interest rate and the GDP growth rate, we noticed the countries that had positive differential (Belgium, Denmark, Greece, France, Italy, Hungary, the Netherlands, Portugal, Romania, Slovenia, Finland, Sweden and UK). The rest of the countries borrowed money at a cost lower than the GDP growth rate. But, empirical evidence shows no relevant pattern that might correlate somehow the public debt-to-GDP ratio, public debt growth rate, GDP growth rate and the implicit interest rate to public debt. It might be argued that some of the highest indebted countries (e.g. Belgium, Greece, Italy or Hungary) ran a 'not so cautious' fiscal policy, considering that the rate of growth of public debt was larger than the GDP growth rate and that these governments borrowed money at a cost higher than the GDP growth rate.

In this context, it is to some importance to assess whether fiscal policy is vulnerable in the sense of being exposed to liquidity and/or solvency risks. The methodology described in Section 3 is applied for the case of all European Union countries (in the following referred to as EU-27). Annual data from Eurostat is extracted for 1970-2012 but may differ from country to country in accordance with the availability. Following equation (4), the required primary balance is estimated and works as a fiscal rule. Then, the errors between the required primary balance and the current primary balance are calculated. The errors are summed up and squared to capture the cumulative excess of the primary balance. The SQCEPB is presented in the graphs below (see Figure 2): 

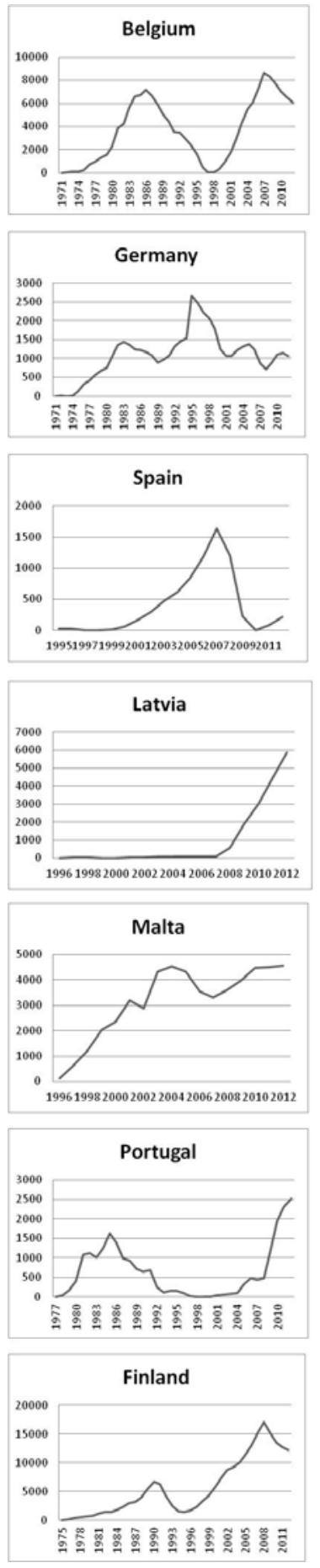
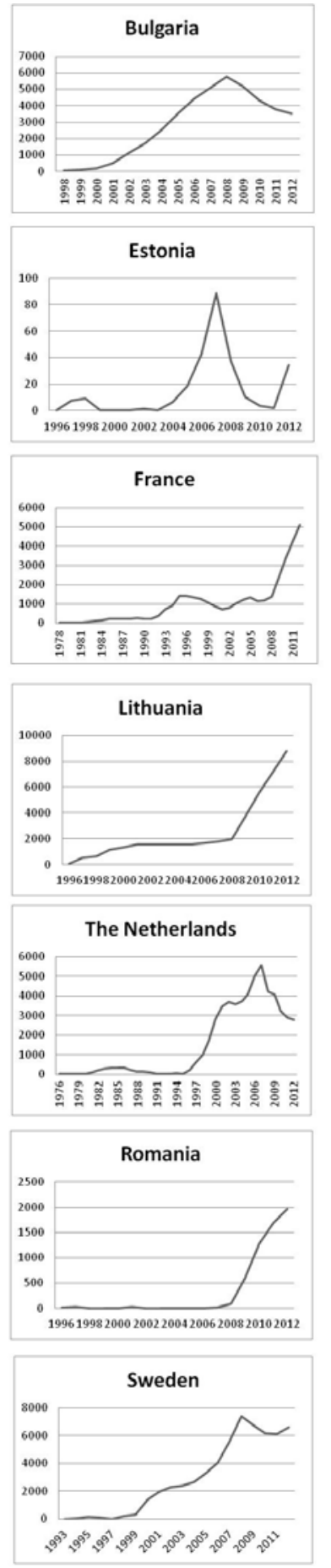
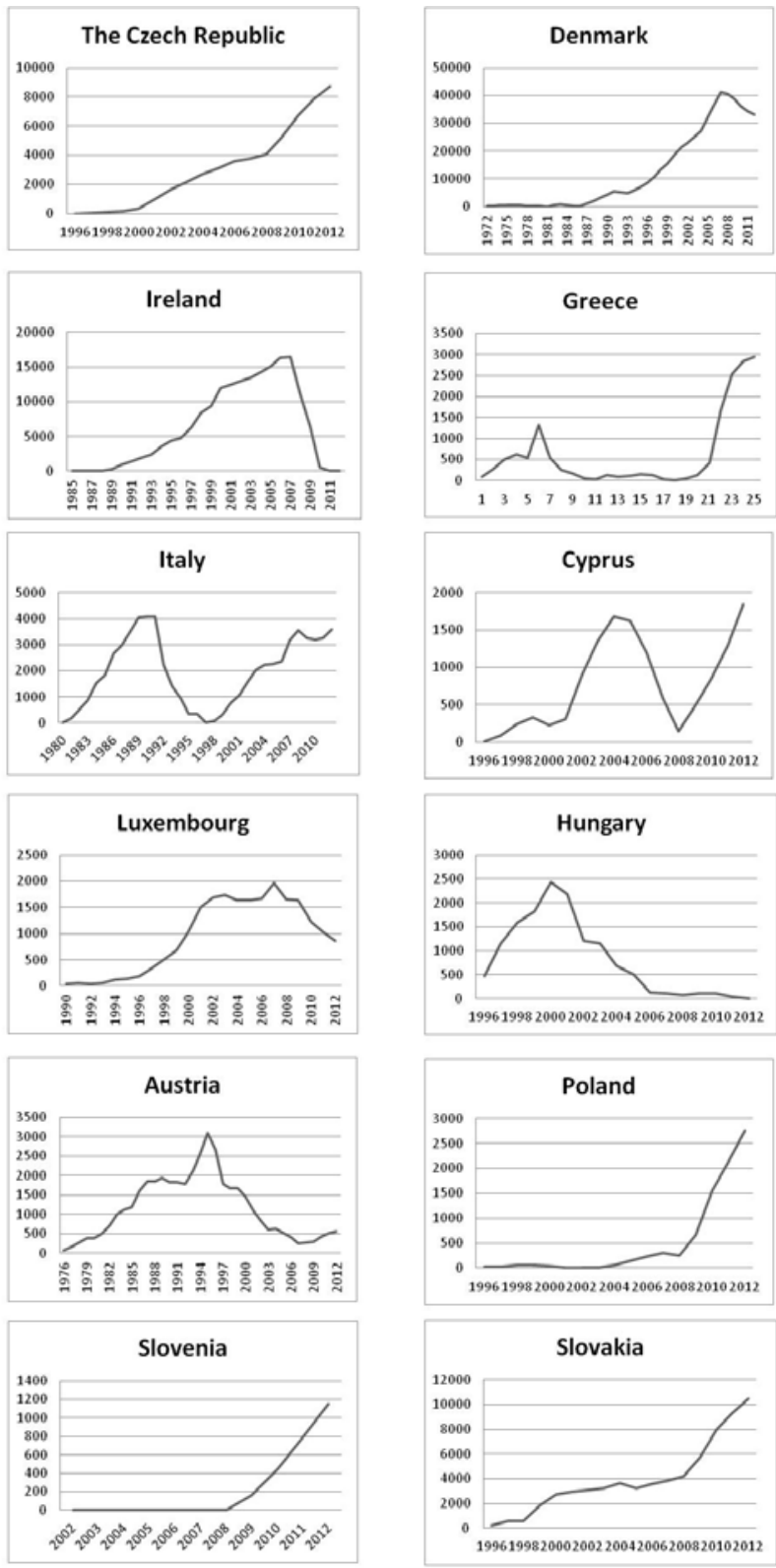

Figure 2. Squared Cumulative Excessive Primary Balance (SQCEPB) for EU-27

One can observe the moments when fiscal policy was vulnerable (see also Table 3). Increasing SQCEPB indicates that governments repeatedly failed in achieving the fiscal rule and that the exposure to liquidity and/or solvency risks is higher. Decreasing SQCEPB points out that government took adjustment actions to restore fiscal policy more closely to the fiscal rule. SQCEPB also shows various degrees of fiscal vulnerability. Reduce exposure is related with low values of SQCEPB. These should represent the first signals for the government that 


\section{Ml Macrothink}

Research in Applied Economics

ISSN 1948-5433

2011, Vol. 3, No. 2: E3

fiscal policy is about to enter into a 'vulnerable' condition and that it requires adjustment. Larger values of SQCEPB reveal the accumulation of errors over many years. These also may be a sign of postponed fiscal adjustments. Generally speaking, government's response may be delayed due to its Ponzi scheme behavior. For instance, if government considers that it has all the eternity to repay its debt or to assess the required primary balance, it may allow for more expansionary fiscal policy by lowering taxation and increasing government spending. Also, government may try to postpone its effort to assess the required primary balance, deteriorating the macroeconomic conditions and allowing for issuing more debt in the long run.

Table 3. Fiscal vulnerability years

\begin{tabular}{|l|l|}
\hline & \multicolumn{1}{|c|}{ Years } \\
\hline Belgium & $1971: 1986,1998: 2007$ \\
\hline Bulgaria & $1998: 2008$ \\
\hline Czech Republic & $1996: 2012$ \\
\hline Denmark & $1972: 1974,1981: 1984,1986: 2007$ \\
\hline Germany & $1971: 1972,1974: 1983,1989: 1997,2002: 2005,2008: 2011$ \\
\hline Estonia & $1996: 1998,2000: 2002,2004: 2007,2011: 2012$ \\
\hline Ireland & $1985: 1987,1988: 2007$ \\
\hline Greece & $1988: 1991,2000: 2001,2002: 2012$ \\
\hline Spain & $1997: 2007,2011: 2012$ \\
\hline France & $1980: 1986,1991: 1995,2002: 2005,2008: 2012$ \\
\hline Italy & $1980: 1990,1998: 2007$ \\
\hline Cyprus & $1996: 1998,2001: 2004,2008: 2012$ \\
\hline Latvia & $1996: 1998,2000: 2004,2006: 2011$ \\
\hline Lithuania & $1996: 2002,2004: 2012$ \\
\hline Luxembourg & $1990: 1991,1992: 2008$ \\
\hline Hungary & $1996: 2000,2008: 2009$ \\
\hline Malta & $1996: 2001,2003: 2004,2007: 2012$ \\
\hline Netherlands & $1979: 1985,1993: 1994,1996: 2002,2004: 2007$ \\
\hline Austria & $1976: 1979,1981: 1989,1992: 1995,2005: 2006$ \\
\hline Poland & $1996: 1998,2002: 2007,2009: 2012$ \\
\hline Portugal & $1977: 1982,1984: 1985,2000: 2012$ \\
\hline Romania & $1996: 1997,2000: 2001,2005: 2012$ \\
\hline Slovenia & $2005: 2007,2009: 2012$ \\
\hline Slovakia & $1996: 2004,2006: 2012$ \\
\hline Finland & $1975: 1990,1995: 2008$ \\
\hline Sweden & $1993: 1995,1997: 2008$ \\
\hline UK & $1971: 1974,1980: 1991,1997: 2002,2006: 2008$ \\
\hline & \\
\hline & \\
\hline
\end{tabular}

We also may notice that for many of the advanced EU-27, fiscal policy had entered into a vulnerable condition since the early ' 70 s (e.g. Belgium, Denmark, Germany, Finland and UK), since the late ' 70 s for the case of the Netherlands and Portugal, and since the early ' $80 \mathrm{~s}$ 
for Ireland, Greece, France and Italy. For most of the new comers (the Central and Eastern European countries, including Malta and Cyprus) fiscal vulnerability has been indicated by SQCEPB since the late '90s. The results also show no continuous increasing of SQCEPB. There are moments when SQCEPB decreased. This point to some fiscal adjustment actions took by the governments to restore fiscal policy to the 'good' path. But, depending on the consistency and on discretionary of such actions, the moments with 'good' fiscal policy were shorter or longer and the policy entered again into the vulnerable condition. Concerning the recent financial turmoil, it also may be observed that all European economies had vulnerable fiscal policies for many years before it hit worldwide. This exposure to liquidity and/or solvency risks made difficult the absorption of such shock and turned them into systemic risk. Most of the Central and Eastern European countries (e.g. Czech Republic, Estonia, Latvia, Lithuania, Poland, Romania, Slovakia, and Slovenia, including Malta and Cyprus) and also some of the advanced economies (e.g. Germany, Greece, Spain, France, and Portugal) still have a vulnerable fiscal policy for 2011 and 2012. This shows that governments were not able to overcome the effects of the economic crisis through a good fiscal policy. For the rest of the countries, SQCEPB indicates a decrease, shortly after the financial crises occurred. We can emphasize the importance of a 'good' fiscal policy, flexible enough to meet the requirements of the fiscal rule, to prevent large deviations from that required primary balance, to reduce the exposure to liquidity and/or solvency risk for a good absorption of exogenous shocks that may occur.

\section{Conclusions}

Recent studies have brought into attention the increased exposure of fiscal policy to liquidity and/or solvency risks due to the growing public debt, to population ageing and to its pro-cyclicality. These decreased its ability to absorb exogenous shocks and the probability to turn them into systemic risk has become higher. In this context, it is to some importance to have an accurate tool of assessing fiscal vulnerability to signal governments to take consistent adjustment actions for preventing large deviations of fiscal policy from its sustainable path in the long run. The new methodology presented in this paper bases on a simple dynamic equation of public debt that allows estimating the required primary balance knowing the rate of growth of public debt. Considering that the required primary balance works as a fiscal rule, deviations of the current primary balance from the required one are calculated. The positive and the negative deviations a treated likewise, arguing that a 'good' fiscal policy should meet exactly the level of the primary balance imposed by the rule. For capturing the impact of failures of the current fiscal policy from the fiscal rule in the long run, the errors are summed up. Considering 'bad' fiscal policy the positive and the negative deviations from the fiscal rule, the summed up errors are squared. The Squared Cumulative Excess Primary Balance is the indicator used for assessing fiscal vulnerability. The methodology is applied for the case of European Union countries on annual data spanned on 1970-2012. The results reveal that all European economies had vulnerable fiscal policy over the period considered for investigation. This also may signal governments to adjust fiscal policy to prevent large deviations from the fiscal rule that may endanger sustainability in the long run. Inconsistent and non-discretionary fiscal adjustments may not be so efficient and fiscal policy can turn on 
again into the vulnerable condition.

Taking into account the novelty of the methodology proposed, further analytical directions may be indicated. First, the model used to estimate the required primary balance should be reconsidered. In that sense, fiscal reaction function can be used because it allows more variables to be included, and, therefore, the estimation of the primary balance might be more accurate. Moreover, government's aim to stabilize public debt should be concerned about. Second, the hypothesis for a 'good' fiscal policy could be relaxed with the respect to the general accepted view. Third, to calculate the errors between the required primary balance and the current one, cyclically adjusted series should be used to capture the discretionary fiscal policy independent of the business cycle. All these aspects for further research may give more relevance for the estimations.

\section{Acknowledgments}

This work was cofinaced from the European Social Fund through Sectoral Operational Programme Human Resources Development 2007-2013, project number POSDRU/89/1.5/S/59184 „Performance and excellence in postdoctoral research in Romanian economic science domain".

Much of this work was completed during my research visit in Centre d'economie de la Sorbonne (CES) at Universite Paris 1 Pantheon-Sorbonne under the supervision of Professor Gunther Capelle-Blancard. This research visit was part of the postdoctoral fellowship program financed through project number POSDRU/89/1.5/S/59184 „Performance and excellence in postdoctoral research in Romanian economic science domain”.

Also, this paper uses results of previous published research (Stoian, A. (2011). Fiscal vulnerability vs. fiscal sustainability: theoretical background. Theoretical and Applied Economics, vol. 5(5(558)(su), pages 541-547; Stoian, A. (2011). A Retrospective Approach on Assessing Fiscal Vulnerability: Empirical Evidence for Overindebted European Countries, forthcoming in Timişoara Journal of Economics), or presented at various conferences (Assessing Fiscal Vulnerability Based on Public Debt Dynamic with Growing Economy and Inflation: Empirical Evidence for European Union Countries, "The Sixth International Conference on Economic Cybernetic Analysis: Global Crisis Effects and the Patterns of Economic Recovery - GCER 2011”, Bucharest Academy of Economic Studies, Bucharest, Romania, 20 ${ }^{\text {th }}$ May 2011).

\section{References}

Afonso, A. (2000). Fiscal Policy Sustainability: Some Unpleasant European Evidence. ISEG Working Paper, 12/2000/DE/CISEP, August.

Afonso, A., \& Rault, C. (2008). 3-Step Analysis of Public Finance Sustainability. The Case of the European Union. European Central Bank Working Paper Series No.908/June.

Afonso, A., Agnello, L., Furceri, D., \& Sousa, R. (2009). Assessing Long Term Fiscal Developments: A New Approach. European Central Bank, Working Paper Series No.1032/March 2009. 
Aizenman, J., \& Pasricha, G. (2010). Fiscal fragility: what the past say bout the future. NBER Working Paper No.16478, October 2010.

Alesina, A. (2000). The Political Economy of the Budget Surplus in the United States. The Journal of Economic Perspectives, 14 (3): 3-19. http://dx.doi.org/10.1257/jep.14.3.3

Allen, M. et al (2002). A Balance Sheet Approach to Financial Crisis. IMF Working Paper $\mathrm{WP} / 02 / 210$.

Balassone, F. et al (2009). Fiscal Sustainability and Policy Implications for the Euro Area. European Central Bank Working Paper Series, No. 994/January.

Balassone, F., \& Franco, D. (2000). Assessing Fiscal Sustainability: A Review of Methods with a View to EMU, in Fiscal Sustainability essays presented at the Bank of Italy workshop held in Perugia, 20-22 January, pp. 21-60.

Baldacci, E. et al. (2011). Assessing Fiscal Stress. IMF Working Paper WP/11/100.

Baldacci, E., McHugh, J. \& Petrova, I. (2011). Measuring Fiscal Vulnerability and Fiscal Stress: A Proposed Set of Indicators. IMF Working Paper WP/11/94.

Brixi, H., Shatalov, S., \& Zlaoui, L.(2000). Managing Fiscal Risk in Bulgaria. Policy Research Working Paper 2282, January 2000, The World Bank.

Chuhan, P. (2005). Debt and Debt Indicators in the Measurement of Vulnerability, in C. Burnside (Eds.), Fiscal Sustainability in Theory and Practice (pp.81-112). The World Bank, Washington.

Ciarlone, A., \& Trebeschi, G. (2006). A multinominal approach to early warning system for debt crisis. Temi di discussione del Servizio Studi Number 588-May 2006, Banca D’Italia.

Corsetti, G., \& Roubini, N. (1996). European versus American Perspectives on Balanced Budget-Rules. The American Economic Review, 86, (2): 408-413.

Detragiache, E., \& Spilimbergo, A. (2001). Crises and Liquidity: Evidence and Interpretation. $I M F$ Working Paper WP/01/2.

Fama, E., Fisher, L., Jensen, M., \& Roll, R. 1969. The Adjustment of Stock Prices to New Information. International Economic Review, 1:1-21. http://dx.doi.org/10.1257/jep.14.3.3

Fatas, A., \& Mihov, I. (2009). The Euro and Fiscal Policy. NBER Working Paper No.14722, February 2009.

Frankel, J., \& Saravelos, G. (2010). Are Leading Indicators of Financial Crisis Useful for Assessing Country Vulnerability? Evidence from 2008-09 Global Crisis. NBER Working Paper No.16047, June 2010.

Furman, J., \& Stiglitz, J. (1999). Economic Crisis: Evidence and Insights from East Asia, in W. Brainard \& P.Goerge (Eds.), Brookings Papers on Economic Activity.The Brookings Institution. 
Ghosh, A., Kim, J., Mendoza, E., Ostry, J \& Qureshi, M. (2011). Fiscal Fatigue, Fiscal Space and Debt Sustainability in Advanced Economies. NBER Working Paper No.16782, February 2011.

Hayes, S. (2011). Fiscal vulnerability: a stocktake. The IFS Green Budget, February 2011.

Hemming, R., \& Petrie, M. (2000). A Framework for Assessing Fiscal Vulnerability. IMF Working Paper WP/00/52, March.

Hemming, R., Kell, M., \& Schimmelpfennig, A. (2003). Fiscal Vulnerability and Financial Crisis in Emerging Market Economies. Ocasional Paper 218, IMF, 2003.

Kotlikoff L., \& Hagist, C. (2005). Who's Going Broke? Comparing Growth in Healthcare Costs in Ten OECD Countries. NBER Working Paper No.11833, December 2005.

Pasinetti, L. (1998). The myth (or folly) of the 3\% deficit/GDP Maastricht 'parameter'. Cambridge Journal of Economics, 1998, 22, 103-116.

Reinhart, C., \& Rogoff, K. (2011). A Decade of Debt. NBER Working Paper No.16827, February 2011.

Rial, I., \& Vicente, L. (2004). Fiscal Sustainability and Vulnerability in a Small Open Economy: The Uruguayan Experience, in Public Debt, edited by Banca D'Italia, Research Department Public Finance Workshop, 2004.

Scott, A. (2010). Government Debt after the Crisis, Politics, Economics and Global Governance: The European Dimensions. Policy Paper no.7-March 2010.

Tanner, E., \& Samake, I. (2006). Probabilistic Sustainability of Public Debt: A Vector Autoregression Approach for Brazil, Mexico, and Turkey. IMF Working Paper WP/06/295.

York, R., \& Zhan, Z. (2009). Fiscal Vulnerability and Sustainability in Oil-Producing Sub-Saharan African Countries. IMF Working Paper WP/09/174.

\section{Notes}

Note 1. Furman, J.; Stiglitz, J. (1999) Economic Crisis: Evidence and Insights from East Asia, in Brookings Papers on Economic Activity, edited by Brainard, William şi Perry Goerge, The Brookings Institution, 1999, pp.5-6.

Note 2. Rial, I.; Vicente, L. (2004) Fiscal Sustainability and Vulnerability in a Small Open Economy: The Uruguayan Experience, in Public Debt, edited by Banca D'Italia, Research Department Public Finance Workshop, 2004, pp.184.

Note 3. Frankel, J.; Saravelos, G. (2010) Are Leading Indicators of Financial Crisis Useful for Assessing Country Vulnerability? Evidence from 2008-09 Global Crisis, NBER Working Paper No.16047, June 2010, pp2.

Note 4. Hayes, S. (2011), "Fiscal vulnerability: a stocktake", The IFS Green Budget, February 2011, pp.61. 


\section{Macrothink}

Research in Applied Economics

ISSN 1948-5433

2011, Vol. 3, No. 2: E3

Note 5. Hemming, R., Petrie, M. (2000), A Framework for Assessing Fiscal Vulnerability”, IMF Working Paper WP/00/52, March, pp.5.

\section{Glossary}

\begin{tabular}{|c|c|c|c|c|}
\hline BE: Belgium & & ES: Spain & MT: Malta & FI: Finland \\
\hline BG: Bulgaria & & FR: France & NL:The Netherlands & SE: Sweden \\
\hline The & Czech & IT: Italy & AT: Austria & UK:United Kingdo \\
\hline Republic & & & & \\
\hline DK: Denmark & & CY: Cyprus & PL: Poland & \\
\hline DE: Germany & & LV: Latvia & PT: Portugal & \\
\hline ET: Estonia & & LT: Lithuania & RO: Romania & \\
\hline IE: Ireland & & LU: Luxembourg & SI: Slovenia & \\
\hline GR: Greece & & HU: Hungary & SK: Slovakia & \\
\hline
\end{tabular}

\section{Copyright Disclaimer}

Copyright reserved by the author(s).

This article is an open-access article distributed under the terms and conditions of the Creative Commons Attribution license (http://creativecommons.org/licenses/by/3.0/). 